drugg did not exist. Antibioties, which were only made available in the 1950's, now account for 25 per cent of the drug bill. The second, issued by the Office of Health Economics, is mainly concerned with the place of the general practitioner in the National Health Service and ghows how his position has altered with the development of drugs (The Personal Health Services : a Perspective of the General Medical and the Pharmaceutical Services. Pp. 31. 28.). As Lord Taylor has said, "To-day the practitioner in the gloomier slum practice can treat pneumonia more effectively than the most eminent specialist was able to do before the War". The most important development in the future should be more concentration on personal preventive medicine. Early detection of such diseases as cancer and diabetes is now possible. The publication states that general practitioners need improved facilities to help them carry out this early diagnosis.

\section{Antibiotics in Food and Feedstuffs}

AT the instance of the Joint Export Committoe on Food Additives of the World Health Organization and the Food and Agriculture Organization, the World Health Organization convened a committoe to oxamine the public health problems likely to arise in connexion with the increasing use of antibiotics in animal feeds as growth promoters, for food preservation and in plant disease control. The Expert Committee appointed has recently reported on its findings and conclusions in a bonklet entitlod The Public Health Aspects of the Use of Antibiotics in Food and Feedstuffs (Technical Report Series. No. 260. Pp. 30. Geneva: World Health Organization; London: H.M.S.O., 1963. I Sw.fr.; 1s. 9d.; 0.30 dollar). The report points out that most of the antibiotics used in food preservation or added to animal feedstuffs are of low toxicity, and, provided regulated quantities are used, the quantities likely to be present as residues in food are very small. The danger exists, however, that penicillin, for example, may causo allergic reactions in humans already sensitized by medical treatment. Chloramphenicol is in a special category, as fatal damage to the bone marrow has occurred in patients treated with therapeutic doses. The Committee believes that further research is desirable in this field. The rapid spoilage of meat in hot climates might, for example, be averted if tetracyclines were used, either by giving the animal pre-slaughter injections, or by treating the carcass. The report stresses that euch uses should be regarded as an exceptional and temporary measure pending the eventual provision of adequate refrigeration. Two useful annexes to the report summarize the practices in different countries in relation to the use of antibiotics in animal feeds and for food preservation.

\section{Farm Forestry}

FARM forestry plays an important part in land use in Sweden, and during $1953-60$ an economic study of this subject was conducted in three localitios south, centre and north Sweden (Kungl. Skogshögskolans Skrifter. (Bulletin of the Royal School of Forestry, Stockholm), Nr. 39: Bondeskogsbruket: Ekonomisk Undersökning Grundad pa Bolföring 1953-1960. (Farm Forestry in Sweden: an Economic Study 1953-1960). Av Th. Streyffert och Chr. von Malortie. Pp. 207. Stockholm: Skogsbibliotekot, Skogshögskolan, 1963). Farm woodlots occupy almost half the forest area of Sweden and some of them are in the best forost area, namely, south Sweden. The practice of farm forestry is an excellent example of integrating different land uses, and the forest properties are regardod as a means of increasing the income of the farmors. In fact, the law prohibits the selling of forest land where it is needed for the support of tho farm. This investigation has produced some interesting statistics, but care should be exercised in interpreting them. The woodlots examined were those where the owners were keen enough to undertake the large amount of record work necessary, and this meant that, on the whole, they were the best managed. Therefore, the statistics may be considered as above average. It was revealed that there was a tendency to overcutting of the prescribed yield in the smaller forests and it is suggested that the lower yield per unit area from the largor forests is due to the owners not being in such need for the money or the labour force being fully occupied with normal work. But efficiency seems to be better on the larger properties where a higher rate of return is recordod. As is to be expected, there are divergences from averages and many of these are due to the woodlots being under the personal management of the owners. This investigation should concern not only the forest economist but also anyone interested in the integration of agriculture and forestry.

\section{Archæology in Ontario}

Bulletin No. 184 of the National Museum of Canadis consists of a detailed report of the excavation of the Donaldson site by J. V. Wright and J. E. Anderson (The Donaldson Site (Anthropological Series No. 58.) Pp. viii +113 (26 plates). Ottawa: Queen's Printer, 1963. 1.50 dollars). The site is located in the Bruce Peninsula of Ontario, and traces of the settlement here include middens, a cemetery and house foundations. The cemetery yielded both single and multiple inhumations in pit graves, some accompanied by personal ornaments. Two house structures, demarcated by post-holes, were recovered; these were rectangular, the largest approximately $25 \mathrm{ft}$. by $15 \mathrm{ft}$., and supported in all by moro than 100 posts. No trace of rebuilding was noticed, and some of the interior posts probably represent a sleoping platform. Pottery from the middens belongs to the Saugeen Focus of the early Middle Woodland period, c. 500 B.c. The stonework includes projectile points, scrapers and choppors, and copper objects were rare. The material seems to show elements allied to other Woodland complexes, and is representative of an economy comparable with the northern Algonkians of historic times.

\section{Earthwork on Overton Down, Wiltshire}

A RECEnT report of a research committeo of the British Association for the Advancement of Science describes the construction of a ditch and bank of chalk in Wiltshire, built partly with primitive tools, partly with modern equipment (The Experimental Earthwork on Overton Down, Wiltshire, 1960. An account of tho Construction of an Earthwork to Investigate by Experiment the way in which Archæological Structures are Denuded and Buried. Pp. viii $+100+8$ plates. Edited by P. A. Jewell. London: The British Association for the Advancement of Science, 1963. 25s.; 4.50 dollars). The object of the exereise, carefully outlined in meticulous detail in this book, is to allow archrologists both of the immediate and of the distant futuro to record through observation and excavation the development of the monument, the degroo of erosion and denudation of the bank, and the degree and mannor of silting of the ditch. This evidence should be of great importance in the interpretation of sections obtained during the exeavation of prehistoric and early historic monuments. A number of objects, including textiles, food, flints and potsherds, have been buried in the bank, and future excavation will show how the various materials have reactod to the conditions of burial. The first of a number of sections has already been cut, although the report on this will not appoar until it has boen combined with another excavation in 1964.

\section{Joseph P. Kennedy, Jr. Foundation Awards}

The Joseph P. Kennedy, Jr. Foundation was established in 1946 by former Ambassador Joseph P. Kennedy in memory of his son, Lieut. Joseph P. Kennedy, Jr. The Foundation engages in a programme of support of 